\title{
No Rights in the Matter: A Phenomenological Inquiry into Grief for Someone Else's Child
}

\section{Bill Underwood}

University of Victoria

\section{A Question Posed}

When parents come together at social gatherings, at some point they talk of their children. What is exchanged, on the surface at any rate, are stories or reminiscences that bring to life the "minute particulars" 1 of the pleasures and pains of childrearing. One story my wife and I often tell at such gatherings is of my son's colic, the only remedy for which proved to be early morning drives through the wet streets of Prince Rupert where, haggard, we would often pass another couple, equally haggard, their child as eagerly alert and curious as ours in its baby seat. Over the years we have refined the story, let it legend in us, and we retrieve it with relish at the proper moment, with a variant in the telling each time, embellishing, lingering over the details. But what do we really do in the telling of such stories, and what are parents doing in this circular, aggregate exchange of the perplexing and affectionate? For the parent, the simple exchange of the experience of parenting is another way of expressing care and love for the particular child and of affirming that child's existence, his or her being, by weaving story. And the exchange of stories, communally told and shared, is a way of celebrating the primal fact of children and the intricate web of human involvement between parent and child. Indeed, in this communal sharing we "render available to all" (Partridge, 1983 , p. 112), the particular story, becoming part of the group's anthology of stories. And in this way, in a symbolic sense, through this community of sharing and laughter, we become involved in the lives of children other than our own.

It is true, of course, that our connection to other children is not the profound and intimate connection of parent and child. There is something in the day-to-day living with a child, the tucking in at night, the Band-Aids, the first step, the tantrums and traumas, that inextricably links parent and child. Who else but a parent would know, intimately, the small eccentricities and mannerisms of their children? In Tyler's The Accidental Tourist (1987) Macon Leary recalls his son's peculiar "endearing habit of bouncing on the balls of his feet when he was

Phenomenology + Pedagogy Volume 81990 
nervous" (p. 18), a heartbreaking habit under the circumstances and rendered in Macon unforgettably. In my own son it is a slight tilt of his head as he savors a private joke or, when he was younger, a peculiar automatic phrase of "Fifty dollar buck" whenever the subject was the price of things, be it a dozen eggs or an airline ticket to Toronto. But what does connection with the child mean for the next door neighbor, the soccer coach, and the good friend of the parents? No one would claim for them the intense involvement, the almost daily felt awareness of the beloved child; but no one could deny, either, the elusive, human relatedness potentially there.

I think back to my own childhood in Portland, Oregon. As children do, I moved in a wayward pack of other neighbor children up and down Cleveland Avenue, seeking adventure in this friend's basement, decorating our bikes with streamers or, on that tarry summer street, ever on the lookout for cars, playing hide and seek and kick the can. Two doors down from mine lived Mrs. Kentner, a stooped, wrinkled lady for whom at certain times, and I really don't know why, three or four of us would detach ourselves from our avocations and, on those hot summer days, sit about her tiny porch and talk with her of this and that while she served cookies and lemonade. And then, as quickly as we came, we rambled away and she would return indoors to whatever life she led in that cool dark interior. Obviously Mrs. Kentner mattered to me or she wouldn't have flashed into my mind as I write these words. But what exactly was I in her life? As a child such a thought never occurred to me, of course. I simply accepted this social relation as natural and inevitable. But how does one "measure" the depth of Mrs. Kentner's connection and feeling for me? What did I mean to her as a mortal being? Looking back over these 35 years I now think that I was simply one of the "neighbor boys" from up the street. After all, I never remember that she called any of us by our names and I imagine, in my reverie, that what we provided for her was more than diversion and possibly a warm and human temporary stay against loneliness. But as an individual boy among the others, what was I to her, and was this relation ever brought to her consciousness? Was I merely "the neighbor boy" from somewhere up the block, important as that might be, or was I maybe more?

Let us take this question and move back to the gathering of parents that initiated our inquiry. Imagine the husband and wife amid a communal circle of other couples relating a story of their daughter, adding one more story to the evening's anthology. If, at that moment, the doorbell were to ring and a police- 
man were to enter to relate the child's sudden, tragic death, we can be sure of the parents' aching and overwhelming response. This is, of course, an unspeakable image and no parent would need such news to bring to consciousness the depth of love for the child. The parents already know. Even our distant, solitary Macon Leary stalking his house at night, sleepless with buried grief over the murder of Ethan, his 12-year-old son, reminds himself over and over not to "think about it" (Tyler, 1987, p. 18) in his futile attempt to keep the pain at bay. But as the door closes and the policeman descends, what of the other parents in the circle, those who have known the child: the next door neighbor, the parents' good friend, the soccer coach? Is it possible, unlike the child's parents, that the breadth and depth of their connection can only be brought to consciousness by that loss? And what of the grief of these peripheral others, in the late child's universe more stars than sun or moon? What is it like to grieve, not for your own, but for someone else's child?

\section{Taking Up the Burden}

As I write this I am aware again of sitting in the United Church on Saltspring Island. I was to be one of Matthew's pallbearers and so sat apart from Susan, my wife. I can remember, being there, filled with a loneliness and need for her to be with me and an ineffable sadness and weariness throughout my body for all the pain of the past three days. For that moment I was beyond tears, and what remained was a heavy, weighted sorrow. And I remember the organ, and the church filling, quietly, slowly, the shuffling of feet and the five other pallbearers one by one seating themselves beside me. And finally Jim and Suzanne and Maxine entering and then Reverend Skinner. But mostly I remember looking and looking at a framed picture of Matthew on the flower-draped coffin. I remember little of the ceremony, several hymns, some inadequate words and then I and five other pallbearers at Matthew's side, six middle-aged men, bearing the coffin to an open hearse waiting outside on Hereford Avenue.

Hold in your mind the image of that funeral service and the burial where the six middle-aged men placed Matthew's coffin on the retaining straps over an open grave, shocking in its gaping depth. Think of the "surroundingness" of those events, of those who have come with their individual griefs to gather at the edges of the grieving family, yet not simply to gather really, but to surround and support that family, and both, gatherers and family, again surrounding a diminutive, still center which is Matthew, "gift of God," being borne to his grave. Here, like our social gathering before, is a communal, sharing circle and, like 
all true circles, it is unbroken. That word communal is singularly key, derived from the Latin communa meaning common, which in turn means "universal, [and] public" (Klein, 1966, p. 321). Donne expresses this same transcendental notion when he reminds us that "any man's death diminishes me, because I am involved in mankind" (1985, p. 243). And so it was with Matthew's funeral and burial as it is with our social gathering, both the expression and sharing of care and love for a particular child, an affirmation of that child's existence. In the one, of course, the circling is an expansion outward in joy, but in the other the circling moves in to surround and support, to caress tentatively, gently, the primal grieving parents, a public sharing in their loss, a universal grief for that child, and in the sharing something of all our loss. In his Logos, Heidegger tells us that, "It is proper to every gathering that the gatherers assemble to coordinate their efforts to the sheltering; only when they have gathered together with that end in view do they begin to gather" (1976, p. iv).

I remember so well grasping the cool metal rung of Matthew's coffin in my right hand and as we lifted, a shock of surprise at my imperceptible lurch, the weight pulling straight to the earth's center at my shoulder. Still in my hand I feel the impress where cold metal left its grooved burden in my flesh. But my burden was not a singular one, for with me five other men my age, circled about Matthew, took up their share of a burden, and some 200 others flowing out of the church about us had also taken up equally as many shares and for whom I, in my particular grief, moving with the slow coffin, was merely and humanly a representatative, taking up for all of us the actual burden of Matthew as he lay dead, the burden of our grief weighted, sagging in our chests, taken on for Jim and Suzanne and Maxine, as best we could, in this public and universal event, taking up some of the burden, no matter how inadequately, of their private grief. Even our solitary, fumbling Macon, his life in a shambles, somewhere in the recesses of his soul, dimly knows this universal truth, that his grief is to be shared. What begins as a diplomatic dismissal of Muriel, the improbable dog trainer of The Accidental Tourist, becomes the purging of a pent-up, year-long grief, a grief Muriel takes up in a miniature communion on her front porch:

He said, "It's Macon."

"Macon?"

The latch clicked and the inner door opened several inches. He saw a sliver of Muriel in a dark-colored robe. She said, "Macon! What are you doing here?" 
He gave her the letter.

She took it and opened it, using both hands .... She read it and looked up at him.

He saw he had done it all wrong.

"Last year," he said, "I lost ... I experienced a ... loss, yes, I lost my ..."

She went on looking into his face.

"I lost my son," Macon said. "He was just ... he went to a hamburger joint and then ... someone came, a holdup man, and shot him. I can't go to dinner with people! I can't talk to their little boys! You have to stop asking me. I don't mean to hurt your feelings but I'm just not up to this, do you hear?"

She took one of his wrists very gently and she drew him into the house, still not fully opening the door, so that he had a sense of slipping through something, of narrowly evading something. She closed the door behind him. She put her arms around him and hugged him. (Tyler, 1987, pp. 199-200)

As Klein (1966) reminds us, grief derives from the Old French, "to burden," and as a verb, grieve, from the Latin, is "to charge with a load, burden" (p. 680). Muriel takes up Macon's burden, encircling it gladly as only a mortal human can.

\section{Responsibility: The Tie That Binds}

At this point we might return to our question: What is it like to grieve for someone else's child? Surely, what has gone before doesn't quite get at the question. Haven't we really described a grief that is the same, whether it be for someone else's child or grandfather or close friend? The answer is no. For in the carrying of that coffin I knew I was carrying a child, for all of us there. And as adults our collective responsibility is to children, something I think I realized early on, passing that other car bearing its extraordinary cargo over the wet, dawn-grey streets of Prince Rupert. At one time I might have put a Band-Aid on this boy I now bore to his grave, or consoled him when he cried, or reasoned with him when he fought with my son, or carried him asleep in my arms. These never happened but that is not relevant. As for the children in both cars 12 years before, my responsibility was always there, vigilant, a condition of my maturity. And that is what made this funeral so powerful in the collective experience of the adults, each of us responsible for this blond-haired boy that I now carried in his coffin, for him my first and final act of responsibility. And maybe here was a pedagogic lesson of adults and children. Grief for someone else's child is a recognition that all children are in the trust of all adults, and it is this which possibly gave sorrow its particular shape that day. 
Have we really unconcealed a quality of grief that we didn't know before? If, taken in its narrow sense, grief as more truly personal pain, genuine bodily anguish, then, yes, I have to a degree sidestepped that experience, and my particular bodily experience of it by focusing on a public manifestation expressed through a formalized ceremony. Yet, as I write this, I realize that grief transcends the body to our "lived relationships with others" (van Manen, p. 177), and not just my relationship with Matthew, but with Jim and Suzanne and Susan and my son Adam, and those with whom I carried the coffin and those with whom I communed that Monday and, ultimately, with life itself. In this sense, then, grief for someone else's child ties us to others, is a responsibility for the vulnerability of the whole and an affirmation of its existence and the weblike connections that make the whole vital with humanness; it is not so much a willingness to take on with others one's part in the shared burden, but rather that one is compelled to do so, called to it, a call that simply cannot go unheeded. It is beyond choice. As Muriel knew so spontaneously, grief for the child calls us to the griever.

\section{Grief Enters}

Susan cried and cried as I held her. She said it was in the paper, she said he had been shot, she said poor Jim and Maxine and Suzanne and after a while I left her and found the Vancouver Sun scattered on her bed and searched through it. It was such a small announcement, tucked near the end of an article on shooting deaths, words something like this: In a related incident 11-year-old Matthew Prendergast of Saltspring Island was accidently shot and killed yesterday by a friend as the boys played with a rifle. Odd, I remember thinking, so small, a paragraph, and Matthew's name. It really didn't mean anything to me. Matthew Prendergast. You read newspapers and there are a multitude of names, some that you recognize and some that you do not, but seldom is one personal, and here was a name I knew, one of a blood-and-bone boy who walked my streets and had birthdays and went canoeing with his father. Yet, here, on this flimsy, cheap page he was a name, grimy and implausible. It simply did not connect. Matthew Prendergast. Dead. Shot. Playing with guns in a house on Saltspring Island. Someone from the North End is quoted as saying everyone is sad. That it's a tragedy. Matthew. Dead. I sat on the bed reading the paragraph over and over. Susan came in. Yes, we must tell Adam. Now? Yes. We must leave Vancouver; we must go back to Saltspring. We must go right to Jim and Suzanne's. Should we? 
Would they want to be alone? No, we should go. Should we phone first? No. And somehow we told Adam and he cried.

\section{Time and Pain}

Adam is my son. How fine it is to write those words. He is mine; he is my son. Does that sound unduly possessive? I don't really care. He is freckled and sports T-shirts to his knees and loves movies and someday, he says, he will be an actor, a star. Good for you, I think, you know already of the imperative of a ruling passion about which to organize your life (Schickel, 1989, p. 62). He has grown away from Matthew these two years, has stepped out from beside him. Somewhere in time Matthew is frozen into a posture of a boy dabbling and paddling in oversized flippers about Wayne's dock, face down in the greeny water of St. Mary's Lake, looking through a scuba mask for frogs and turtles. Adam has moved away from that now, sloughed off old passions like his sticker collection and taken on new ones, has grown some, heavier, not so soft and full about the face, but longer legged, coltish, more like a teenager. But Matthew ... he will remain always the boy paddling about the dock, always eleven, poking among the reeds, seeking out frogs and turtles, or drifting lazily away on his inner tube toward the dark, watery heart of the lake. And this is such a specific local grief, an urgent temporal poignancy where, like Macon, we realize it is "the immunity to time that [makes] the dead so heartbreaking" (Tyler, 1987, p. 354).

That night Susan and I lay in bed and talked, as Adam slept in his room surrounded by posters of Michael J. Fox and The Beatles. It was odd. We talked of this and that. About Matthew. And Adam. Jim. Suzanne. Maxine. The Accident. Sasha, Matthew's brother. And as we talked, something began to stir in me. And then we talked of loss. And Adam again. And then simply talked. I said how awful and unfair, never to see Matthew again. How unbearable, how for their entire lives this would never go away, not really, only to maybe bury itself, but to come back, to see other children grow into their youth, to move and experience and be, and to know your child would never move from sleep, would be slipping farther and farther away from you and the children his age.

Grieving for someone else's child is a grieving for the parents who must watch through time your child age and step away from their own. In this sense it is an identification, that this could have been your child. There is also a hint of something not unlike guilt here, although not quite guilt, and manifest in a physical poignancy that swelled and ached in my chest and 
throat, knowing that my son growing into himself would be there as a reminder. My body incorporated this knowledge, yet whether the grief was in my mind first, and then my body, or I grieved because my body ached and my tears welled I cannot say, but I know I was in pain for the incessant, small reminders that would stab at my friends; the sensation was, then, a physical, painful omniscience of the past slipping away and the future like a relentless hall of mirrors reflecting back images of the self aging and a thousand ghostly lost Matthews caught in time. And maybe that was simply the ultimate pain, that grieving for someone else's child was grieving for the parents' sense of time and those events in time that would never be fulfilled, complete. Never have I felt time and the body so irrefutably yoked.

And the birthdays. The Christmasses. Then to grow away from that day, his life, receding, how you would want to hold the interval before his death forever. But always to be reminded. Something stirred and stirred in me and I felt my voice grow husky. Susan said, "Why don't you cry? You haven't cried." And I said, "Poor Jim. Poor Suzanne. Oh Jesus." I felt that word, poor, felt it thoughout my body. I was shaking and Susan said, "Go ahead and cry." And grief welled up through me and out my mouth and eyes, uncontrollably. And I was crying and crying, for Jim and Suzanne and Maxine, at the unfairness of it, at the utter waste of it. Then I knew he was dead. That Matthew was dead. And I was crying for Matthew.

\section{No Rights In the Matter}

In 1603 Ben Jonson, the great Jacobean poet and playwright, lost his seven-year-old son to the plague. In "On My First Son" Jonson expresses the sheer-edged severance from this "child of my right hand" and vows, through his pain, never to love anything so much again (1985, p. 254). Such grief, bordering on the egotistical and self-indulgent, is a parent's grief, as implacable as a blackened monolith on a stormswept plain-and one in which I can believe. For like Jonson's boy I too believe Adam has been "lent" to me, that there is nothing of forever here, the only surety that he will age and grow into his own, and although I am confident of a constancy, our love for one another, I am also aware of a continuous drifting away of this boy, as he was, as he is, this child of my right hand.

But what of my grief for Matthew? It could never be as Jonson described. After all, who was I to be crying in the night in the arms of my wife for a boy I hardly said more to than, "Hi Matthew, how're you doing?" or "My God, are you ever shooting up!"? Ask me to itemize my own son's dreams and quirks, his 
abilitites, his insecurities, the actions that irritate and the gestures that endear, and I could write forever. I could tell stories of changing his diapers on the top of a washing machine in Prince Rupert, or I could recreate the briny smell of his eraserfresh body leaping from green breakers rolling onto the Oregon Coast. But for Matthew I had, and have, nothing approximating a full store, maybe a shelf, and that with a quirky hodgepodge of goods: that he was crazy about soccer, that his smile was wide and generous, that he loved his brother, that he was always the first off Wayne's dock into the cold water of St. Mary's Lake. I had, I realize, rationally and analytically, no business with tears, yet I still grieved.

In "Elegy for Jane" Roethke writes of the death of a young student in his literature class who was thrown from her horse. He writes beautifully and movingly of this young person's full presence in the world, of her joy, the depth of her sorrow, and of Roethke's wish to "nudge" her back to life, into Being. I cannot speak for other Roethke enthusiasts, but as I move into the last lines of this great poem I see, in my mind's eye, the poet, alone at the grave of his student, speaking "the words of my love/I, with no rights in this matter,/Neither father nor lover" (1966, p. 102). I, too, had "no rights in this matter" of Matthew's death. Although a star in my universe he was nothing remotely central to me, assuredly nothing like sun or moon. I never carried him to bed, never read him stories, never disciplined him, never attended parent-teacher meetings to discuss his marks: never did establish and share the multitude of minute contact points that enmesh us in our own children's lives. And yet, like Roethke, I too found myself standing "over this damp grave" speaking "the words of my love." And I realize now, to grieve for someone else's child is simply a primordial fact of what it means to be human, that there is no entrance requirement, that the grief needs no justification or excuse, but that it is simply and wholly and fundamentally there, an "is" beyond analysis and the deft calculations of common sense.

\section{Note}

1. A phrase from William Blake.

\section{References}

Donne, J. (1985). Meditation 17. Adventures in English literature.

New York: Harper \& Row.

Heidegger, M. (1976). Basic writings (D.F. Krell, Ed.). New York:

Harper \& Row.

Jonson, B. (1985). On my first son. Adventures in English literature.

New York: Harcourt Brace Jovanovich. 
Klein, E. (1966). A comprehensive etymological dictionary of the English language. Amsterdam: Elsevier.

Partridge, E. (1983). Origins: A short etymological dictionary of modern English. New York: Greenwich House.

Roethke, T. (1966). Elegy for Jane. The collected poems of Theodore Roethke. Garden City, NY: Doubleday.

Schickel, R. (1989, June 5). A bothered school spirit. Time, pp. 23, 82. Tyler, A. (1987). The accidental tourist. Markham, ON: Penguin.

Van Manen, M. (1989). Researching lived experience: Human science research for an action sensitive pedagogy. London: Althouse. 